\title{
Spatial development strategies for a liveable city: Parthenia
}

\author{
S. Çelikyay \\ Department of Landscape Architecture, University of Bartın, Turkey
}

\begin{abstract}
As the cities experience urbanization, there is a need for urban strategies to control growing areas under urbanization. People in cities need to live in a healthy and secure built environment. It is necessary that planning and design strategies should be extended in the context of sustainable development of the cities. Major approaches, principles and strategies of "planning and design for liveable and sustainable cities" take into consideration natural, cultural and historical heritage. With the aim of transmitting historical and cultural heritage to the next generation and organizing public and open green spaces in the planning process, the present urban landscape would be transformed so that liveable and sustainable cities would be built. The major dynamics for shaping the urban form depend on geography and history. While some of the cities in the world, where a river passes through, have been planned using the form of the river in their geographic location, some of them have been planned considering the historical urban texture in their cultural components. In this paper, urban strategies have been developed for the city of Bartın (Parthenia) which has two major heritages, Bartın River (Parthenios) and its historical urban core, waiting for to be valued.

Keywords: Bartın, Parthenia, Parthenios, sustainable city, urban strategies.
\end{abstract}

\section{Introduction}

While cities experience economic development, their natural, historical, and cultural heritage are continually damaged. In order to change the course of this destruction, an emergent need is for new urban policies to provide protection of natural resources and improve living conditions of dwellers. This can be achieved with the guidance of sustainable development principles. As specified in the report of the World Commission on Environment and Development with the title of "our 
common future", sustainable development requires to not only supply the needs of the current generation but also to consider the needs of future generations [1]. It means that environmental consequences of economic development should be considered so that future generations can have natural resources to make them meet their own requirements. From economic, social and environmental aspects, development must be equitable liveable and viable [2]. As emphasized by Campbell, the planner must redress the balance between the targets of economic growth and planning so as to not endanger the ecosystem [3]. In order to build a bridge between economy and ecology, it is necessary that urban planners, architects and landscape architects in order to ensure the best integration of the projects within their urban environment must work in collaboration. In addition to these professional experts, environmentalists, administrators, and whoever participates in the decision making process on the future of the city, these all should be in cooperation in order to achieve environmental protection, spatial organization and economic development without exhausting natural resource.

In most of the developed and developing cities in the world, sustainability is the major concept guiding urban growth and economic development. In the growing and developing process of the cities, when they experienced an increasingly growing built environment, it is essential that spatial development strategies, which include development scenarios on urban space should be determined. Spatial development strategies to guide urban growth and to provide urban development with planning and programmes should be implemented from large to small scale and from planning to design. From the spatial aspect, the concept of sustainability comprises not only environmental and ecological but also architectural dimension. It can be defined as "planning and design with nature" in order to both protect, continue and transmit natural and cultural values to the next generations. In addition to natural resources and environmental components, historical heritage as tangible elements of cultural values must be taken into account for sustainability.

Under the guidance of emphasized common approaches for sustainable cities, local dynamics giving the soul to the cities are of great importance. That is because "the soul of every city takes its form with regard to its geography" [4], thus, geographical elements, historical and cultural objects are essential components where their priority varies from city to city. Shaping the urban geography, as one of these components, rivers are the most dynamic components to constitute the landscape characteristics in the cities. Throughout history, peoples have preferred to live on riversides. From the very early beginning of human life, water has played a fundamental role in the development of societies [5]. Therefore, rivers and surrounding areas which are most important components of landscape should be used wisely in order to maintain sustainability and allow future generations to benefit from them. The other factors affecting city form and shaping the urban fabric are historical and cultural elements. Traditional architecture or historical buildings as the cultural traces of people who have lived in the past is a tangible cultural heritage to be transmitted to future generations. 


\section{Parthenia (the city of Bartın)}

The city of Bartın in Turkey is located in north Anatolia, near the Black Sea (figure 1). As one of the most ancient settlements in the Paphlagonia region [6], Bartın which was called Parthenia in ancient times [7], is one of the special cities in Turkey which has a river passing through. It is mentioned in written sources that the name of the settlement on the riverside of Bartın River was Parthenia in ancient times and then it changed to Bartin in time [7]. As major factors which constituted the settlement and shaped its form, there are two important heritages in Parthenia. The first of them is Bartın River which was called Parthenios in the past, and it is also mentioned in historical sources that it was named after the Greek poet: Parthenios who lived in Parthenia [8]. The second heritage from the past is the historical city core in historical urban texture in which there are a lot of traditional architecture samples.

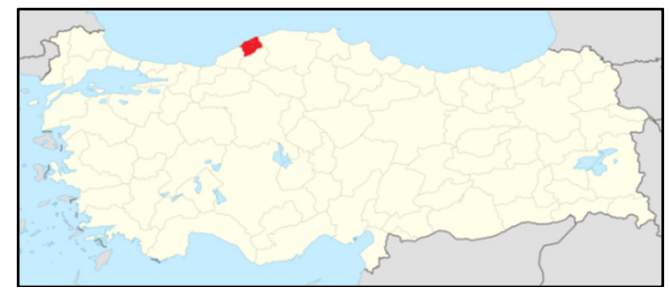

Figure 1: $\quad$ Location of Bartın (Parthenia) in Turkey.

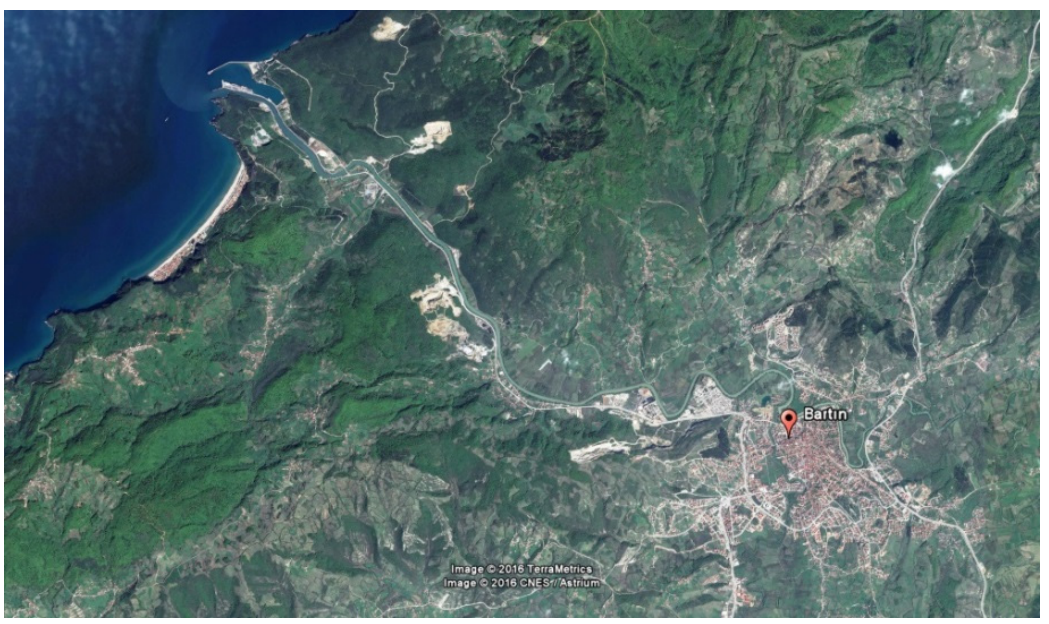

Figure 2: $\quad$ Parthenia and Parthenios extending over the Black Sea. 


\subsection{Parthenios (Bartın River)}

Shaping the beginning of the urban fabric in the settlement, Parthenios has great potential because it was a unique river for water transport in the past, in Turkey. Therefore, the riverside was the most living space for humans in the past both from a commercial and a cultural point of view. Parthenios was the most important natural and cultural resource for settlement. Under the historical story in the past, it built the borders of Bithynia on the west side and Paphlagonia region on the east side. The name of Parthenios has been often mentioned in ancient sources from the 8th century B.C. [9]. Parthenios was the major determinant when human beings made the decision of where to live, in the past. The old quay of Parthenios, which is the intersection area between Parthenia and the river, is the starting point of the settlement as a market place, a permutation place, where traders exchanged goods. Traders settled in this market place over time, and then this place transformed to a settlement. Three branches of the river inosculate in the old quay area and originate from the river of Parthenios. From the old quay, the river extends over the Black Sea $12 \mathrm{~km}$ in length (figure 2). Thanks to the rich forest resources in the region, lumbering was a widespread business field in Parthenia. Therefore, building of wooden ships was an important sector due to the transportation provided by the river. The old quay district of Parthenios was the wooden ship building area (figure 3(a)). Building of these traditional wooden ships, which are peculiar to Parthenia, continued until the 1970s.

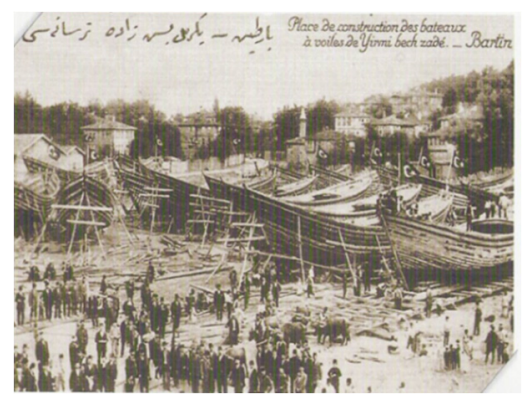

(a)

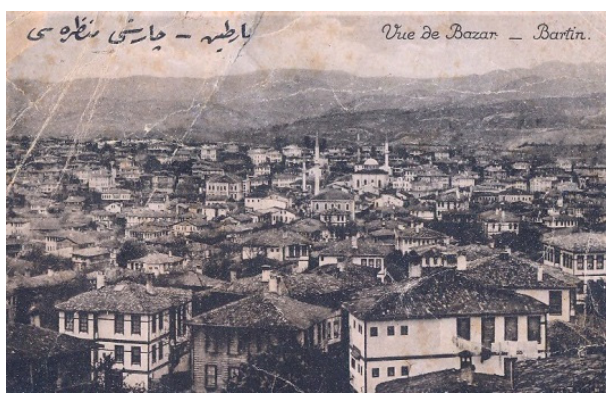

(b)

Figure 3: (a) Wooden ship building in the old quay district [10]; (b) Compact historical urban texture in the past [10].

\subsection{Historical urban texture}

Another dynamic shaping urban form guiding the spatial development of the city is the historical urban texture in the city core. From a morphological aspect, the city core is located on a peninsula surrounding the river which is connected to the surrounding areas by four bridges (figure 4). All the traditional buildings constituted the compact historical texture of the city in the past (figure 3(b)). In addition to the wooden ships, all the traditional houses in the city were built using wooden materials; wood-framed houses have timber roof scaffolds, ceilings, 
floors, ladders, wardrobes and cupboards. In addition, their windows and doors are also wooden material. Identity and originality are the major characteristics of the historical urban texture with its components. Traditional wooden houses, khans, public bath, mosques, a monumental fountain, and some buildings are original components reflecting traditional architecture and socio-cultural life in their age (figure 4). In particular, the monumental fountain at the entry point of the pedestrian zone is a landmark of both the historical urban core and the city (figures 4 and 5).

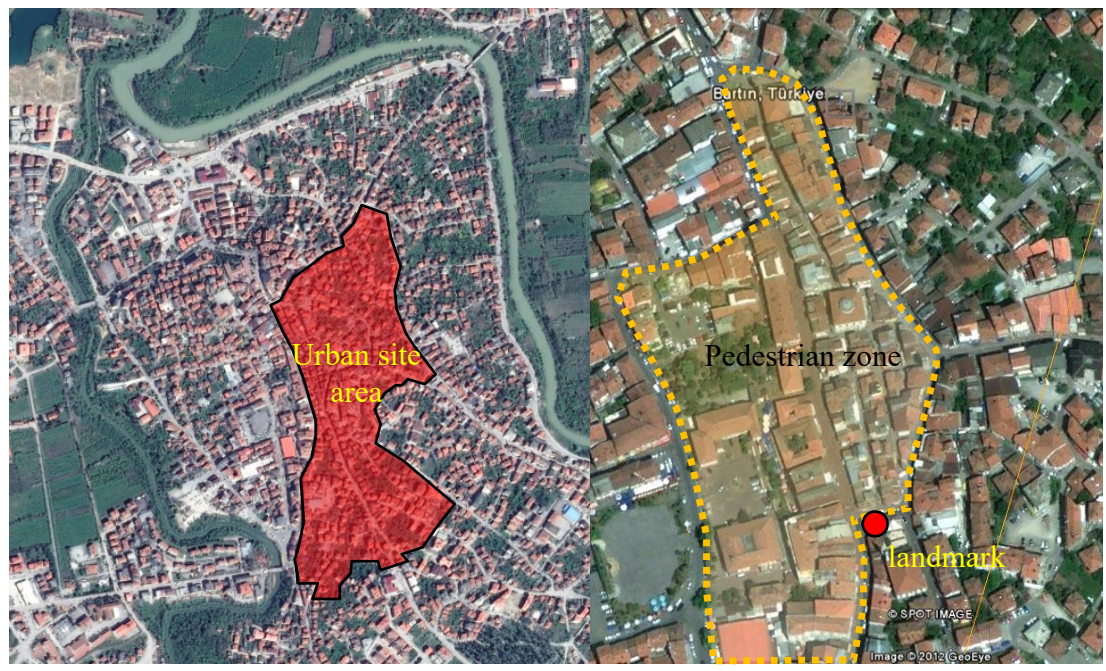

Figure 4: Current urban site area, and current pedestrian zone in the city core.

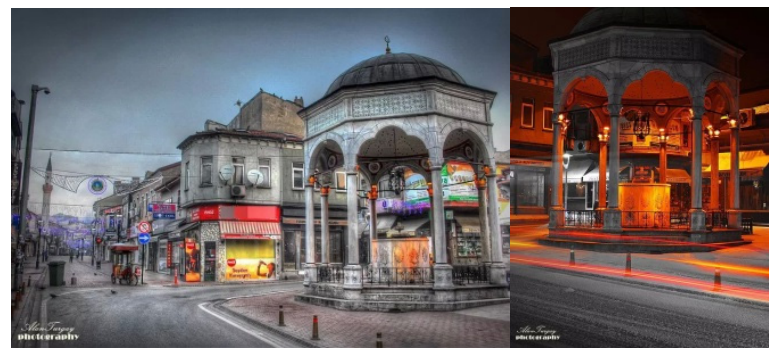

Figure 5: Monumental fountain as a landmark in the city [11].

\subsection{Problems and potentials of Parthenia}

As a summary highlighted in Table 1, flood risk, pollution and misuse of land have had an impact on both Parthenios and the surrounding areas. Although flooding on a small scale is frequently experienced without harm, a great extent flood disaster is about a secular event experienced by the people living in the city. In recent years, the reason for that is erosion caused by deforestation in the river 
basin. In the river basins, due to erosion and heavy rainfall, the amount of sediment frequently increases and makes the water level of the river increase which again causes flooding in the basins [12]. Parthenios experiences this flooding cycle a few times in a year. Parthenios is also affected by physical and chemical pollution stemming from the domestic waste of the surrounding community and chemical waste of industrial establishments built on the riverside. Misuse of land in the region of Parthenios is another problem which needs an urgent solution so that the potential of natural resources can be assessed for the future of the city. Both sides of the river are natural, containing biodiversity and ecological characteristics and there are also endemic species peculiar to the riverside. In this regard, some studies have been conducted on both the urban and riversides. As a result of the analysis based on flora and vegetation conducted by Y1lmaz [13], it was determined that "among 93 herbaceous plant taxa belonging to 26 familias, both Euro-Siberian and Mediterranean elements 22 taxa become prominent, and five taxa are endemic for the region" [13]. Although the river corridor of Parthenios has experienced a big change under the pressure of anthropogenic impacts from far in the past, it is still possible to encounter vegetation groups belonging to the natural zone along the river corridor [14]. Furthermore, river corridors in urban area also provide living space for the birds in Parthenia [14]. The studies show that the riversides of Parthenios have a great ecological and biological potential to be assessed in the context of the "planning with nature" principle.

Table 1: Major components, problems and potentials in the city of Parthenia.

\begin{tabular}{|c|c|c|}
\hline Major components & Problems & Potentials \\
\hline $\begin{array}{l}\text { Parthenios and } \\
\text { surroundings }\end{array}$ & $\begin{array}{l}\text { - Flood risk } \\
\text { - Domestic waste } \\
\text { - Physical and chemical } \\
\text { pollution } \\
\text { - Industrial establishments } \\
\text { - Misuses of the lands }\end{array}$ & $\begin{array}{ll}\text { - } & \text { Biodiversity } \\
\text { - } & \text { Natural site area } \\
\text { - } & \text { Demands for } \\
\text { recreational activities } \\
\text { - } \\
\text { Needs for open green } \\
\text { spaces }\end{array}$ \\
\hline Historical city core & $\begin{array}{l}\text { - Decrease of registered } \\
\text { traditional wooden } \\
\text { houses } \\
\text { - Misidentification in built } \\
\text { environment } \\
\text { - Traffic flow density } \\
\text { - Noise and visual } \\
\text { pollution }\end{array}$ & $\begin{array}{l}\text { - Financial support for } \\
\text { restoration given by the } \\
\text { Ministry of Culture } \\
\text { - Trends for urban } \\
\text { renovation } \\
\text { - Needs for pedestrian } \\
\text { zones } \\
\text { - Needs for change }\end{array}$ \\
\hline
\end{tabular}

In comparison with all of the traditional buildings constituting the compact historical texture of the city in the past (figure 3(b)), today, traditional houses seem to be unconnectedly located in the urban area. Though the numbers of traditional architectural samples registered as cultural properties by the Ministry of Culture in both the peninsula and surrounding area was 674 in the 1980 s, now, only 241 wooden houses remain registered and a narrowed urban site area [6]. This decrease of registered buildings as cultural properties is a hard and legal proof on the urban 
conservation approach (unconsciousness) in urban policies. While most of the old traditional houses became more damaged due to the lack of financial support of their owners to make architects draw and survey, restoration and restitution projects, today, the city has experienced a misidentification in the built environment. Although the number of registered traditional houses have decreased, in recent years, owners of traditional houses have tended to renovate their houses thanks to the financial support given by the Ministry of Culture. This popular tendency creates opportunities for these houses, as traditional architecture models, to be protected and sustained. In addition, due to the tendencies of the owners, shops in the historical city core have been experiencing a change from visual and functional aspects, but it seems pretty obvious that there is a need for an urban guide to control this change.

\section{Spatial development strategies for Parthenia}

The fundamental strategy to guide the spatial development of Parthenia is to make a connection between the city and the river, and plan the city as a settlement in which a river passes through. It is of great importance that Parthenios, which was the unique river for water transport in the past, was connecting Parthenia to Egypt due to trade relations. Historical urban core is the other dynamic factor to guide urban development. In the context of spatial development strategies, basic approaches and principles from ecological planning to urban design can be essential tools of an action plan to guide the future of the city. In addition, there is an urgent need for urban policy to enable the use of these spatial development tools in order to realize sustainability of the city.

\subsection{Ecological planning in the region of Parthenios}

While planning is a form of spatial organization to improve social wellbeing depending on the needs of the community, land use decisions in the planning process build the relationship between human/life/nature and consider interrelations of them as an holistic system [15]. In order to make humans and nature co-exist, the natural and ecological characteristics of a place should be considered in the decision-making process, besides considering the demands of the community.

The highlights of ecological planning in the region of Parthenios are

- natural resource analysis,

- $\quad$ strategic environmental assessments,

- land use suitability analysis,

- $\quad$ zoning for conservation and utilization and

- a green network system.

The first step of ecological planning is that natural resources should be analysed so that they can be used in accordance with their natural potentials. Strategic environmental assessments are also necessary at the beginning of the planning process, instead of a stage to be implemented after planning $[16,17]$. By means of strategic environmental assessments, investigation of the interaction between 
present land uses and their effects on nature (soil, water, biotope and bioclimate) is an essential process, before making decisions in regard to the future of the city. Recreational and residential lands use should be determined in accordance with a suitability analysis of the land. There are two conservation areas in the surrounding area of Parthenios. One of them is a natural site declared as a first degree natural conservation area, thanks to its ecological and biological characteristics, along with the two sides of the river, and the other is an archaeological site on a small area. Determination of conservation zones and recreational zones for public use should be implemented by taking these areas to be protected into account. In ecological planning, this step is significant from the aspect of effective and economic use of natural resources without harming them. One of the basic principles of planning for liveable and sustainable settlements is to increase public spaces and open green spaces. In particular, assessment of surrounding areas of Parthenios, as public open green spaces in balance between protection and utilization, is of great importance. Urban green spaces provide many environmental and social services improving the quality of life in cities, i.e., air filtering, microclimate regulation, noise reduction, rain water drainage, recreation and social interaction [18]. The connection between the river and the city, and the interaction between them is also an attractive issue for city planners and architects from a landscaping aspect.

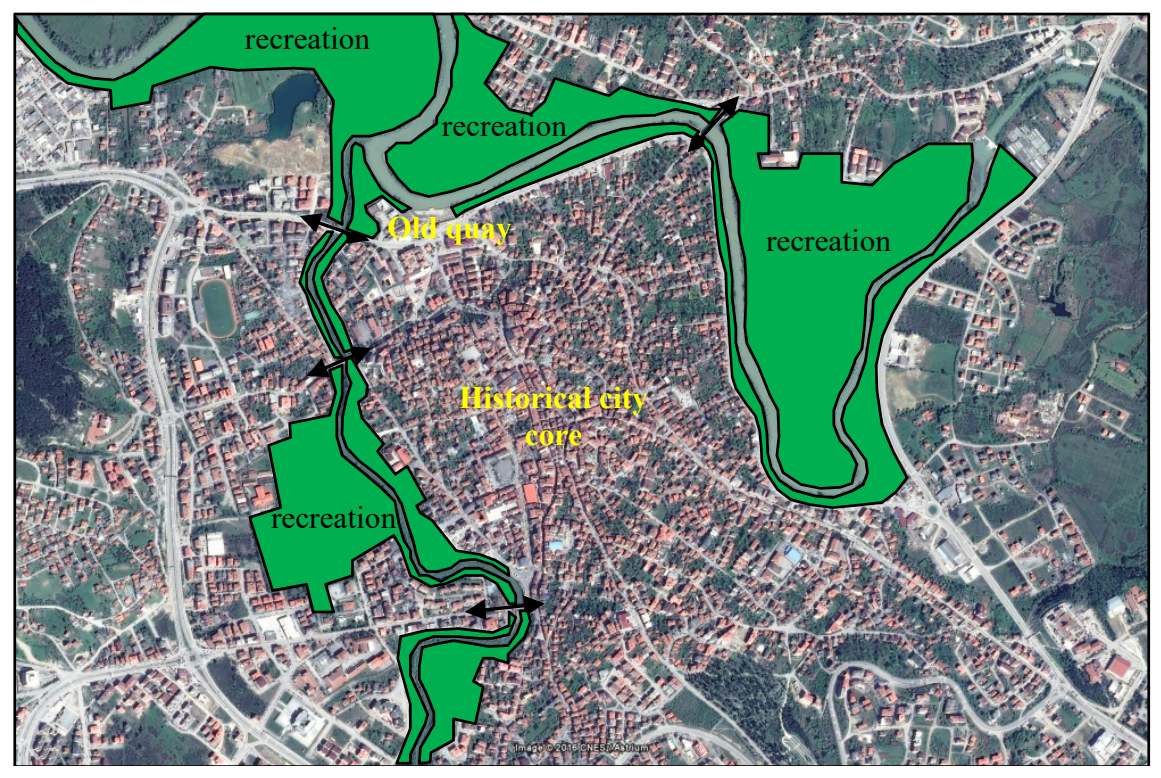

Figure 6: Green spaces proposal on riversides of peninsula in city core.

In Parthenia, people living in a residential area on the peninsula or visitors coming to that place cannot be aware of where they are - on a peninsula surrounding the river or on a lowland from a geographical aspect. Thus, green spaces (including green corridors and green ways) integrated with the whole green 
network system in the city can be created along with the river and surroundings of the peninsula (figure 6). Giving recreational function to these open green spaces, new waterfront places can be created for the community for socio-cultural ceremonies as experienced in the past. In the landscape, the $12 \mathrm{~km}$ length of riverside from the old quay to the Black Sea also gives an opportunity to be assessed for recreational and social activities. Connecting community to the nature, open green spaces have a great potential for tourism. Furthermore, "having the typical traditional form and countryside landscape, the agricultural...villages would be the attractive destinations for ecotourism and agricultural tourism" [5]. As nature-based tourism, ecotourism can contribute to achieving protection of biodiversity [19] in the ecological corridor on the riversides of Parthenios. As one of the goals based on urban ecology, to be achieved in the region, the increasing ecological function of urban areas also benefits the community. Increasing the green factors in urban spaces may contain such social advantages as a decrease in conflict [20]. In addition, Parthenios with both riversides extended to the Black Sea is an ecological corridor to improve the microclimate of the city, in addition to providing living spaces for fauna. Thus, building green corridors is highly recommended, according to the principle of protecting the river valley from the negative impacts of misuse of riverside land [21].

\subsection{Community planning in the region of Parthenios}

As a decision-making process regarding "the future of the city" [15], planning not only considers the physical characteristics of a place, but also takes into account the sociocultural dynamics of the community. Thus, planning is a spatial scenario written for community life. It determines where residence or cultural, recreational actions take place, and where they build their commercial, industrial establishments. In addition to ecological planning strategies in the region of Parthenios, the following highlights from the community planning and design aspects also should be used as a guide.

- Reconciling the city with the river;

- Fictionalizing riverward living in the city;

- Identity of the city where the river passes through;

- Providing effective land use with the recreational projects for the community;

- Accessibility to the waterfront with the open public spaces;

- Adding dynamism to the public spaces with the walking-bicyclingrecreational areas along the river;

- Connecting the historical city core to the old quay district.

Although Parthenios was a place for some festivals on certain days in a year, now, it seems as if forgotten by the community. It is time to reconcile city and community with the river. There were some important places on the riverside of Parthenios from a cultural aspect, which still linger strongly in urban memory. As a custom from the past, hidrellez festivals, celebrated in the first week of May, were organized on the riverside land. People boarded small boats on the river in groups for entertainment and to row. This kind of cultural act can be one of the 
"non-tangible elements of urban heritage,..., which play a role for the articulation of space use and the built environment" [22]. Making a connection between the old quay and the historical city core which includes khans, public bath, mosques, current pedestrian zone (figure 4) must be extended to the old quay district. The old quay and surroundings areas can be planned for recreational and cultural acts as in the past. Considering natural resource potential, enabling and sustaining an ecological balance, it is possible that making the city a place for recreational and cultural acts in collaboration with ecological planning and community planning approaches (figure 6).

\subsection{Urban conservation planning}

In some of the cities of the world, urban conservation policies ensured the preservation of historical and cultural heritage [23]. The holistic conservation of the cities having historical and cultural components of heritage from the past can be achieved when they are taken into account as a whole with all its parts. The core of every traditional historic city has a life based on many years of history and human experience [24]. Therefore, conservation planning is an essential tool to achieve preserving and sustaining historical and cultural values, which have a special meaning for community and adding value to places. Sustainability of cultural identity of the cities needs not only conservation principles at a building scale, but also conservation policies at an urban scale.

Identity and originality are the major characteristics of historical urban texture with its components in Parthenia. Traditional wooden houses, khans, public baths, mosques, and some buildings in the historical urban core are original components reflecting traditional architecture and socio-cultural life in their age. Although the first conservation plan in regard to the urban site area including 674 registered traditional buildings in Parthenia was implemented in 1982 [25], the plan has changed many times since then. As a result of these changes, some previously registered buildings have been destroyed and some of them have become more damaged. Today, a narrowed urban site area within the 241 registered wooden houses as models of traditional architecture covers the historical city core. It is necessary that all traditional houses outside the current urban site area should be considered, taking into account the number of registered houses, the boundaries of the urban site should be extended for holistic conservation and sustainability.

\subsection{Urban design projects}

Urban design as an intersection area between urban planning and architectural design makes a bridge between them. Bridging the gap between planning and architectural scale, urban design makes the cities visibly harmonic with the planning decisions. Urban design is a favourable tool to satisfy the demands of the community for liveable, confident and sustainable cities [26]. Urban design is a design process which considers social environment and the community, in addition to buildings, streets and avenues to constitute the physical environment in the cities. As a community design, adding value to cultural and social life, urban design has a positive effect on the cities. Giving new function to the urban design 
of spaces is a good tool for renovating the historical environment with the aim of conservation and sustainability.

With the urban design projects including renovation and re-functioning of buildings and public places, it is possible to transform them into new living spaces for the community in Parthenia. Although the city core has a pedestrian zone, there is a current need to make larger pedestrian zones, instead of increasing the density of motor vehicles in the historical urban core. In addition, the demand for more public spaces is still a current issue, especially from the point of view of the young and student population. Design of ergonomic public spaces and ergonomic urban furniture is also a key issue for urban designers to make the urban environment comfortable, secure spaces for users.

Highlights of urban design studies in Parthenia are

- determination of architectural characteristics of traditional buildings;

- analysis of building typologies;

- analysis of facades as boundaries of public spaces;

- $\quad$ extended pedestrian zones;

- $\quad$ ergonomic, secure spaces;

- urban design guides to consider the image of the city with all components.

\subsection{Urban policy}

As emphasized above, planning approaches, planning and design tools are of great importance, but of more significance is urban policies to adopt a holistic perspective using these tools. Although the planning approaches and contents are differently mentioned above in order to emphasize their importance as if they are separate from each other, all of them absolutely should be within the scope of an integrated holistic plan including ecological principles, conservation approaches, community planning aspects, and design for community concepts.

The principle strategy for the social, cultural, spatial, and environmental development of the city is that there is an emergent need for a new urban policy to make the city liveable and sustainable. An urban management policy is a major determiner factor as to whether the city will become liveable or will still experience conflict with nature and history. An urban policy must be to encourage the community to participate in the decision making process about their life, as one of the good governance principles. Participation of the local community in urban policy has become an increasingly significant issue [27]. The city of Parthenia needs a sensitive urban management policy to use planning and design tools transmitting its heritage to the future.

\section{Conclusion}

In the city of Bartın, two major components that need change and transformation gain priority to guide determination of spatial strategies in regard to the future of the city. Both Parthenios and the historical city core are dynamic factors to transmit the city to the future according to the present needs and tendencies of the community. Under the guidance of sustainable development principles, achieving 
a protection-utilization balance of natural resources, assessment of the city's potentials can build a positive and harmonic relationship among humans, nature and history.

In this paper, I especially preferred using "Parthenia and Parthenios" instead of "Bartın and Bartın River", so that I fetch them from urban memory and bring them to light in order to get the attention they deserve. That is because, as major dynamics generating the city and shaping its form and adding value to its identity, places and buildings rooted in urban memory also have spatial meanings in the memory of community life. In order to make the community proceed toward the future of the city, it is suggested that they remember the place where they have lived, and which spatial memories they store in the past. The common past of the community is highly recommended to be explored so that their common future can be fictionalized by planners and architects and they can live peacefully in their common sustainable city.

\section{References}

[1] WCED, Our Common Future, From One Earth to One World, An Overview by the World Commission on Environment and Development, 1987. http://www.un-documents.net/our-common-future.pdf

[2] Tanguay, G.A., Rajaonson, J., Lefebvre, J-F., Lanoie, P., Measuring the sustainability of cities: an analysis of the use of local indicators. Ecological Indicators, 10, pp. 407-418, 2010.

[3] Campbell, S., Green cities, growing cities, just cities?: Urban planning and the contradictions of sustainable development. Journal of the American Planning Association, 62(3), pp. 296-312, 1996.

[4] Sözen, M., Nice 25 Y1llara, Yerel Kimlik, 43, pp. 16-17, 2015.

[5] Phong, L.H., The relationship between rivers and cities: influences of urbanization on the Riverine zones - a case study of Red River zones in Hanoi, Vietnam. WIT Transactions on Ecology and the Environment, Sustainable Development and Planning Series, 193, pp. 27-43, 2015.

[6] Culture Inventory Bartın, Bartın Valiliği İl Kültür ve Turizm Müdürlüğü, pp. 15-17, 2011.

[7] Bartin from Mythology to Travellers, Inventory of Culture and Tourism, Directorate of Culture and Tourism, p. 17, 2007.

[8] Aşçığlu, E., Bartın, Bartın Ticaret ve Sanayi Odası Yayını, pp. 7-8, 2001.

[9] Çam, F.B., Parthenia in the ancient time, Bartın Üniversitesi Çeşm-i Cihan: Tarih ve Kültür Araştırmaları E-journal 1(1), pp. 3-17, 2014.

[10] Asma, Ç., Private Archive, Bartın, 2015.

[11] Alan, T., Private Photograpy Archive, 2015.

[12] Kolawole, O.M, Olayemi, A.B, Ajayi, K.T., Managing flood in Nigerian cities: risk analysis and adaptation options - ilorin city as a case study, Archives of Applied Science Research, 3(1), pp. 17-24, 2011. http://scholarsresearhlibrary.com/archive.html

[13] Yilmaz, H., Obsevations on meadow vegetation of Bartin City. Ekoloji, 13(51), pp. 26-32, 2004. 
[14] Nayim, Y.S., Ayaşligil Y., Contributions to the flora between Amasra and Inkum (Bartın) located in Western Black Sea Region. Biological Diversity and Conservation, 8(3), pp. 92-113, 2015.

[15] Çelikyay, S., Research on new residential areas using GIS (Chapter 3). Innovations in Design \& Decision Support Systems in Architecture and Urban Planning, eds. J.P. van Leeuwen, H.J.P. Timmermans, Springer; Dordrecht, The Netherlands, pp. 221-233, 2006.

[16] Çelikyay, S., Strategic environmental impact assessment in ecological planning process and a case Study on Bartin City. Journal of the Bartin Faculty of Forestry, 8(9), pp. 10-22, 2006.

[17] Çelikyay, S., Ecological planning for livable and sustainable cities, a case study for Bartın city. Proceedings of the International Conference on Sustainable Development of Contemporary City, Bakü, Azerbaijan. pp. 4048, 2013.

[18] Szulczewska, B. Giedych, R., Borowski, J., Kuchcik, M., Sikorski, P., Mazurkiewicz A., Stanczyk T., How much green is needed for a vital neighbourhood? in search for empirical evidence. Land Use Policy, 38, pp. 330-345, 2014.

[19] Açıksöz, S., Cetinkaya, G.Ç., Uzun, O., Nemutlu, F.E., İlke, E.F., Linkages among ecotourism, landscape and natural resource management, and livelihood diversification in the region of Suğla Lake. International Journal of Sustainable Development \& World Ecology, 23 (1), pp. 15-27, 2016.

[20] Pickett, S.T.A., Cadenasso, M.L., Linking ecological and built components of urban mosaics: an open cycle of ecological design. Journal of Ecology. 96, pp. 8-12, 2008.

[21] Çelikyay, S., Cengiz, B., Ecological planning strategies on Bartın River region. WSEAS Transactions on Environment and Development, 8(2), pp. 1091-1096, 2006.

[22] Steinberg, F., Conservation and Rehabilitation of urban Heritage in Developing Countries. Habitat International. 20(3), pp. 463-475, 1996.

[23] Lee, S.L., Urban conservation policy and the preservation of historical and cultural heritage: The case of Singapore. Cities, Issues in Urban Conservation. 13(6), pp. 399-409, 1996.

[24] Assari A., Mahesh T.M., Assari E., Conservation of Historic Urban Core in Traditional Islamic Culture: Case Study of Isfahan City. Indian Journal of Science and Technology, 5(1), pp. 1970-1976, 2012.

[25] Çelikyay, S., Design Guides in Urban Site Areas, Bartın Case, [thesis], Mimar Sinan Fine Arts University, İstanbul, 1995.

[26] Bornberg, R., Identity by Spatial Design: Topos, a principle derived from historic and vernacular cultures. Urban Design International, 13, pp. 182200, 2008.

[27] Raco, M., Assessing community participation in local economic development-lessons for the new urban policy. Political Geography, 19, pp. 573-599, 2000. 